\section{Herbicide Applications and Incorporation Methods Affect Dazomet Efficacy on Bermudagrass}

\author{
Matthew D. Jeffries ${ }^{1,4}$, Travis W. Gannon ${ }^{1}$, W. Casey Reynolds ${ }^{2}$, \\ Fred H. Yelverton ${ }^{1}$, and Charles A. Silcox ${ }^{3}$
}

AdDitional INDEX wORDs. fluazifop, glyphosate, line-intersect analysis, soil fumigant, turfgrass renovation, visual cover, weed control

SuMmary. Turfgrass renovations commonly involve changing cultivars or species that are better suited for a given setting. Common bermudagrass [Cynodon dactylon (L.) Pers.] is a perennial turfgrass that is difficult to eradicate before renovations, and poses contaminant concerns for the subsequent stand. Dazomet is a granular soil fumigant that has activity on various pests, including common bermudagrass. Field research was conducted from 2015 to 2016 in Raleigh, NC and College Station, TX to evaluate dazomet treatments including various combinations of soil incorporation (irrigation- or tillage-incorporated) and sealing (tarp or no tarp) methods, application rates [291, 291 followed by ( $\mathrm{fb}$ ) 291,468 , or $583 \mathrm{~kg} \cdot \mathrm{ha}^{-1}$ ], and fluazifop-P [fluazifop $\left(0.4 \mathrm{~kg} \cdot \mathrm{ha}^{-1}\right)$ ] $+\mathrm{glyph}-$ osate $\left(2.8 \mathrm{~kg} \cdot \mathrm{ha}^{-1}\right.$ acid equivalent) application(s) for established common bermudagrass control. Overall, treatments required fluazifop + glyphosate before dazomet application for acceptable control ( $>90 \%$ cover reduction) at 42 and 46 weeks after initial treatment (WAIT) in Texas and North Carolina, respectively. Soil-incorporation results varied by location, with dazomet application $\left(583 \mathrm{~kg} \cdot \mathrm{ha}^{-1}\right) \mathrm{fb}$ tillage resulting in $\geq 88 \%$ cover reduction across locations, while acceptable control from irrigation incorporation was only observed in North Carolina. Tarping did not improve efficacy when tillage incorporation at the maximum label application rate provided acceptable control, suggesting practitioners may eliminate this procedure. Information from this research will aid turfgrass managers in developing cost-effective, ecologically sound common bermudagrass eradication programs before renovations.

$\mathrm{B}$ ermudagrass (Cynodon sp.) accounts for $\approx 33 \%$ of managed turfgrass areas on golf courses in the United States, and is predominantly grown in the southeast, southwest, and transition zone (Lyman et al., 2007). In these areas, it is the predominant turfgrass species selected for use on golf course fairways and tees due to its superior drought, heat, and traffic tolerance, as well as its fine texture, dense canopy, and excellent performance at low mowing heights (Turgeon, 2008). Despite these positive attributes, golf course superintendents sometimes renovate bermudagrass areas, at which point its hardy, perennial growth habit may be

${ }^{1}$ Department of Crop and Soil Sciences, North Carolina State University, 101 Derieux Street, Raleigh, NC 27695-7620

${ }^{2}$ Department of Soil and Crop Sciences, Texas A\&M University, 370 Olsen Boulevard, College Station, TX 77843-2474

${ }^{3}$ Amvac Chemical Corp, Product Development, 220 Paper Mill Circle, Lincoln University, PA 19352

${ }^{4}$ Corresponding author. E-mail: mdjeffri@ncsu.edu. doi: 10.21273/HORTTECH03564-16 problematic due to contamination of the successive stand (Doroh et al., 2011). Contamination from previously planted grasses can adversely affect aesthetics and functionality of the newly established turfgrass (Brosnan and Breeden, 2009).

Methyl bromide is a restricted-use pesticide that was the standard for fumigating turfgrass areas before renovation due to its superior efficacy on soilborne fungi, nematodes, and weeds; however, due to its classification as a Class I ozone-depleting substance, methyl bromide use in turfgrass systems was phased out in the first decade of the 2 lst century (United Nations Environment Program, 2009; U.S.
Environmental Protection Agency, 2016). Due to this phase out, turfgrass managers currently rely predominantly on the nonselective herbicide, glyphosate, for bermudagrass eradication. While eradication is possible, Johnson (1988) reported three glyphosate applications $\left(1.6 \mathrm{~kg} \cdot \mathrm{ha}^{-1}\right.$ acid equivalent) over 3 months were required for $99 \%$ control 10 months after treatment. Ultimately, the time required for glyphosate-bermudagrass eradication on golf courses can result in significant revenue losses associated with the prolonged regrassing period, and potentially compromise establishment of subsequent warm-season turfgrasses by reducing the establishment period before dormancy onset.

Dazomet is a granular soil fumigant designed to be soil-incorporated by mechanical/physical or water methods. Following incorporation, dazomet reacts with water to produce methyl isothiocyanate, a gas that controls various fungi, insects, nematodes, and weeds (Brosnan and Breeden, 2009; Unruh et al., 2002). Under favorable conditions, methyl isothiocyanate formation is rapid (dazomet soil half-life $<24 \mathrm{~h}$ ), at which point it can volatilize and escape from the soil profile reducing control (Fritsch and Huber, 1995; Park and Landschoot, 2003). For this reason, management practices such as tarping and tillage are recommended to reduce atmospheric losses.

Dazomet soil incorporation via cultivation is recommended for agricultural uses; however, this practice is not desirable on wide-scale turfgrass renovations and can be problematic on certain topographies (e.g., steep slopes). In addition, dazomet soil incorporation via cultivation alone may provide unacceptable control. Unruh et al. (2002) reported dazomet (392 $\left.\mathrm{kg} \cdot \mathrm{ha}^{-1}\right)$ provided 98\% common bermudagrass control in Jay, FL, 6 weeks after treatment

\begin{tabular}{llll}
\hline $\begin{array}{l}\text { Units } \\
\begin{array}{l}\text { To convert U.S. to SI, } \\
\text { multiply by }\end{array}\end{array}$ & U.S. unit & SI unit & $\begin{array}{l}\text { To convert SI to U.S., } \\
\text { multiply by }\end{array}$ \\
\hline 0.3048 & $\mathrm{ft}$ & $\mathrm{m}$ & 3.2808 \\
9.3540 & gal/acre & $\mathrm{L} \cdot \mathrm{ha}^{-1}$ & 0.1069 \\
2.54 & inch $(\mathrm{es})$ & $\mathrm{cm}$ & 0.3937 \\
1.1209 & $\mathrm{lb} / \mathrm{acre}$ & $\mathrm{kg} \cdot \mathrm{ha}^{-1}$ & 0.8922 \\
$\left({ }^{\circ} \mathrm{F}-32\right) \div 1.8$ & ${ }^{\circ} \mathrm{F}$ & ${ }^{\circ} \mathrm{C}$ & $\left({ }^{\circ} \mathrm{C} \times 1.8\right)+32$
\end{tabular}


(WAT) and 93\% control 44 WAT; however, it was less effective in Arcadia, FL, as control declined to $45 \%$ and $44 \%$ on 5 and 15 WAT, respectively. The authors suggested inconsistent results might be due to nonuniform dazomet distribution in the soil profile (Unruh et al., 2002). Applicators are recommended to cover treated soil with a plastic tarp, roll it, and/or irrigate to seal fumigant vapors into the soil, which can improve efficacy and reduce off-target movement potential (Amvac Chemical Corp., 2014). Park and Landschoot (2003) reported covering the soil with a plastic tarp immediately after dazomet application at $194,29 \mathrm{l}, 340$, or $388 \mathrm{~kg} \cdot \mathrm{ha}^{-1}$ provided $\geq 98 \%$ annual bluegrass (Poa annua L.) seedling reduction; however, nontarped dazomet provided $\geq 92 \%$ seedling reduction only at 340 or $388 \mathrm{~kg} \cdot \mathrm{ha}^{-1}$. The authors applied 0.5 - and 0.25 -inch water immediately after application in year 1 and 2 , respectively, and $0.25 \mathrm{inch} / \mathrm{d}$ through $4 \mathrm{~d}$ (Park and Landschoot, 2003). This may have reduced annual bluegrass control in nontarped plots, as current label recommendations suggest applying $l$ inch of water on the day of dazomet treatment, and up to 0.5 inch of water through the following $3 \mathrm{~d}$ (Amvac Chemical Corp., 2014).

Previous research has shown that applying herbicides before dazomet application can increase long-term control. Doroh et al. (2011) reported hybrid bermudagrass [Cynodon dactylon $\times$ Cynodon transvaalensis Burtt-Davy] control using dazomet may be improved by applying glyphosate $\left(4.5 \mathrm{~kg} \cdot \mathrm{ha}^{-1}\right) 2$ weeks before dazomet application. Furthermore, glyphosate improved bermudagrass control during renovations from hybrid bermudagrass to zoysiagrass (Zoysia japonica Steud. $\times$ Zoysia matrella L.), as glyphosate $\mathrm{fb}$ dazomet resulted in less cover $(7 \%)$ than dazomet alone (71\%) at 15 weeks after establishment (Doroh et al., 2011). Contrarily, Brosnan and Breeden (2009) reported seashore paspalum (Paspalum vaginatum $\mathrm{Sw}$.), a warm-season turfgrass, control was not improved following fluazifop $\left(0.42 \mathrm{~kg} \cdot \mathrm{ha}^{-1}\right)+$ glyphosate $(5.6$ $\left.\mathrm{kg} \cdot \mathrm{ha}^{-1}\right)$ application before dazomet application $\left(506 \mathrm{~kg} \cdot \mathrm{ha}^{-1}\right)$ compared with dazomet alone.
Although previous research has shown herbicides, irrigation, tillage, and tarping herbicides can improve bermudagrass control following dazomet application, minimal efforts have been made to evaluate all of these practices in tandem. Considering implementing such practices comes with additional expenses associated with product costs and labor, efficacious, efficient programs need to be identified. Furthermore, tarping and tillage can increase worker exposure and are not feasible in some scenarios (Branham et al., 2004). The objective of this experiment was to determine the impacts of various combinations of herbicides, irrigation, tillage, and tarping on bermudagrass control in North Carolina and Texas with dazomet.

\section{Materials and methods}

Site DesCRIPTIONs. Field experiments were initiated on l June 2015 in Raleigh, NC (Lake Wheeler Turfgrass Field Laboratory; lat. $35.738369^{\circ} \mathrm{N}$; long. $78.678706^{\circ} \mathrm{W}$ ) and 22 June 2015 in College Station, TX (Texas A\&M University Turfgrass Field Laboratory; lat. $30.617761^{\circ} \mathrm{N}$; long. $96.365594^{\circ} \mathrm{W}$ ) to evaluate the effects of herbicide timing and incorporation method on dazomet performance in various climatic conditions and soil types in the southern United States. The soil type in North Carolina was a Cecil sandy clay loam (fine, kaolinitic, thermic typic Kanhapludult), measuring $6.4 \mathrm{pH}$ and $1.9 \%$ by weight organic matter. The soil type in Texas was a Zack fine sandy loam (fine, smectic, thermic Udertic Paleustalfs), measuring 6.2 in $\mathrm{pH}$ and $<1 \%$ by weight organic matter. At both locations, research was conducted on established common bermudagrass maintained at 2 inches height, with plots measuring $2.4 \times$ $3.9 \mathrm{~m}$ (0.5 m alleyways).

EXPERIMENT INITIATION. Initial $0.4 \mathrm{~kg} \cdot \mathrm{ha}^{-1}$ fluazifop (Fusilade ${ }^{\circledR}$ II Turf and Ornamental; Syngenta Crop Protection, Greensboro, NC) +2.8 $\mathrm{kg} \cdot \mathrm{ha}^{-1}$ acid equivalent glyphosate (Roundup PROMAX ${ }^{\circledR}$; Monsanto, St. Louis, MO) applications were made to select plots $7 \mathrm{~d}$ before initial dazomet application ( 1 and 22 June 2015 in North Carolina and Texas, respectively) using carbon dioxidepropelled sprayers equipped with flat-fan nozzles (XR 8002 VS, TeeJet
Flat-Fan Nozzles ${ }^{\circledR}$; Spraying Systems Co., Wheaton, IL) calibrated to deliver $45 \mathrm{gal} / \mathrm{acre}$. Sequential fluazifop + glyphosate treatments were made on 1 July 2015 and 2 Aug. 2015 in North Carolina, and 24 July 2015 and 20 Aug. 2015 in Texas for plots receiving two or three applications, respectively. All plots were core aerified $(0.75$ inch diameter by 3 inches depth) $3 \mathrm{~d}$ before trial initiation, to affect $\approx 10 \%$ of the trial area (International Sports Turf Research Center, 2016). All plots were irrigated daily from 3 to $\mathrm{ld}$ before trial initiation to ensure sufficient soil moisture at dazomet application, and $\mathrm{l} \mathrm{d}$ before dazomet application, all plots were scalped (0.5 inch height of cut) to conform with label recommendations (Amvac Chemical Corp., 2014). At the day of initial dazomet application, select plots were tilled (two parallel passes at 6 inches depth) using a tractor-mounted rotary tiller before dazomet applications. Dazomet was applied using a 0.9- $\mathrm{m}$ drop spreader at rates including 291, $291 \mathrm{~kg} \cdot \mathrm{ha}^{-1} \mathrm{fb} 291,468$, and 583 $\mathrm{kg} \cdot \mathrm{ha}^{-1}$ (Table 1). After the initial dazomet application was performed, various tillage, rolling, irrigation, and tarping combinations were performed at prescribed timing.

Dazomet tillage incorporation was conducted similarly to trial initiation tillage. Dazomet irrigation incorporation was watered by hand with a single-outlet hose for a prescribed time period to deliver 1 inch (231 s), 0.5 inch (116 s), 0.25 inch $(58 \mathrm{~s})$, or 0.125 inch $(29 \mathrm{~s})$ water at 0 , 1,2 , and $3 \mathrm{~d}$ after dazomet application, respectively. Treatments including a second dazomet application and irrigation incorporation were performed using the same protocol. Rolling was performed using a tractor-mounted roller filled with water and was done immediately after dazomet applications to plots receiving tillage. Tarps were applied by hand using clear plastic (HDX 6 Mil Clear Plastic; The Home Depot Corp., Atlanta, GA), sealed on borders with soil, and removed after 1 week. Plots were undisturbed for 6 WAIT, at which time routine mowing ( 2 inches height of cut) commenced.

Data collection. Plots were evaluated visually for bermudagrass cover estimated on a $0 \%$ (no bermudagrass cover) to $100 \%$ (complete bermudagrass cover) scale at 8,15 , 
Table 1. Dazomet (DAZ) treatment descriptions and incorporation methods for field studies conducted at Raleigh, NC and College Station, TX.

\begin{tabular}{|c|c|c|}
\hline$\underline{\text { Herbicide }\left(\mathrm{kg} \cdot \mathrm{ha}^{-1}\right)^{\mathrm{z}}}$ & Timing $(d)^{y}$ & DAZ incorporation \\
\hline $\operatorname{DAZ}(291)$ & 7 & Irrigate \\
\hline FLU + GLY fb DAZ (29l) & $0 \mathrm{fb} 7$ & Irrigate \\
\hline $\operatorname{DAZ}(291)$ fb DAZ (291) & $7 \mathrm{fb} 12$ & Irrigate \\
\hline FLU + GLY fb DAZ (291) fb DAZ (29l) & $0 \mathrm{fb} 7 \mathrm{fb} 12$ & Irrigate \\
\hline DAZ $(468)$ & 7 & Till $\mathrm{fb}$ roll \\
\hline DAZ $(583)$ & 7 & Irrigate \\
\hline FLU + GLY fb DAZ (583) & $0 \mathrm{fb} 7$ & Till fb roll \\
\hline FLU + GLY fb DAZ (583) & $0 \mathrm{fb} 7$ & Till $\mathrm{fb}$ roll $\mathrm{fb}$ tarp \\
\hline FLU + GLY & 0 & - \\
\hline $\mathrm{FLU}+\mathrm{GLY}$ & 0 & Till \\
\hline $\mathrm{FLU}+\mathrm{GLY}$ fb FLU + GLY & $0 \mathrm{fb} 30$ or 32 (North Carolina or Texas) & - \\
\hline $\mathrm{FLU}+\mathrm{GLY} \mathrm{fb}$ FLU + GLY fb FLU + GLY & $0 \mathrm{fb} 30-32 \mathrm{fb} 56$ or 49 (North Carolina or Texas) & - \\
\hline
\end{tabular}

$\mathrm{fb}=$ followed by.

${ }^{2}$ Fluazifop (FLU) applied at $0.4 \mathrm{~kg} \cdot \mathrm{ha}^{-1}$ and glyphosate (GLY) applied at $2.8 \mathrm{~kg} \cdot \mathrm{ha}^{-1}$ acid equivalent; $1 \mathrm{~kg} \cdot \mathrm{ha}^{-1}=0.8922 \mathrm{lb} / \mathrm{acre}$.

'Day 0 applications initiated on 1 June 2015 in North Carolina and 22 June 2015 in Texas.

and 46 WAIT in North Carolina, and $5,10,16$, and 42 WAIT in Texas. Bermudagrass cover was also determined by line-intersect analysis at 15 and 46 WAIT in North Carolina $(0.1 \times$ $0.1 \mathrm{~m}, 322$ intersections), and 16 and 42 WAIT in Texas $(0.1 \times 0.1 \mathrm{~m}$, 792 intersections). Intersections with bermudagrass beneath them were summed and divided by the total intersects to estimate percent cover (Hoyle et al., 2013).

EXPERIMENTAL DESIGN AND statistical analyses. Four replications of each treatment were arranged in a randomized complete block design at both locations and appropriate non-dazomet controls were included for comparison. Data were subjected to analysis of variance (ANOVA) using the SAS general linear model procedure (version 9.3 for Windows; SAS Institute, Cary, NC). Treatment was a fixed effect, whereas location and replicate were considered random as described by Carmer et al. (1989). Main effects and interactions are presented accordingly, with precedent given to significant interactions of increasing magnitude (Steel et al., 1997). Means were separated according to Fisher's protected least significant difference test at $P<0.05$ level and Pearson correlation coefficients $(P=0.05)$ were determined to quantify the relationship between bermudagrass cover determined by visual estimate and line-intersect analysis.

\section{Results and discussion}

COMMON BERMUDAGRASS CONTROL. ANOVA revealed a treatment-by-location interaction $(P<$ $0.0001)$; therefore, data were sorted by location and date, and presented accordingly. Pearson correlation coefficients showed a strong positive relationship between cover determined via visual estimates and lineintersect analysis in North Carolina at $15(r=0.97, P<0.0001)$ and 46 $(r=0.92, P<0.0001)$ WAIT, as well as in Texas at $16(r=0.91, P<$ $0.0001)$ and $42(r=0.99, P<$ $0.0001)$ WAIT, indicating visual bermudagrass cover estimates increased proportionally with cover determined from line-intersect analysis (Table 2). These findings agree with Hoyle et al. (2013), who reported correlations between visual cover estimates of large crabgrass [Digitaria sanguinalis (L.) Scop.], a common weed in turfgrass systems, and lineintersect analysis were $r=0.93$ to $0.98(P<0.001)$ across two experimental runs. Therefore, visual bermudagrass cover estimates are presented and discussed to focus on practices that affect common bermudagrass control from dazomet treatments.

Acceptable bermudagrass control in North Carolina occurred when fluazifop + glyphosate was applied 1 week before dazomet treatments. Applications of dazomet alone resulted in $45 \%$ to $83 \%, 70 \%$ to $85 \%$, and $76 \%$ to
$85 \%$ cover at 8,15 , and 46 WAIT, respectively (Table 3 ). Differences at 8 WAIT among dazomet-alone applications dissipated at later evaluation dates, with no differences detected between application rates or incorporation method at 15 WAIT, as well as single vs. sequential applications at 46 WAIT. Fluazifop + glyphosate application before dazomet application(s) reduced bermudagrass cover to $\leq 10 \%$ from 8 to 46 WAIT. Within these treatments, a single dazomet application $\left(291 \mathrm{~kg} \cdot \mathrm{ha}^{-1}\right)$ resulted in bermudagrass cover ( $1 \%$ to $6 \%$ ), which is comparable to a $583 \mathrm{~kg} \cdot \mathrm{ha}^{-1}$ rate $(0 \%$ to $2 \%$ ) and a sequential application of $291 \mathrm{~kg} \cdot \mathrm{ha}^{-1}(0 \%$ to $3 \%)$. This suggests fluazifop + glyphosate application before dazomet application can improve bermudagrass control, and may allow practitioners to effectively control bermudagrass using the maximum current labeled rate that uses soil incorporation by water. Doroh et al. (2011) reported dazomet $(388$ $\left.\mathrm{kg} \cdot \mathrm{ha}^{-1}\right)$ or glyphosate alone $(4.5$ $\mathrm{kg} \cdot \mathrm{ha}^{-1}$ ) resulted in $71 \%$ and $73 \%$ hybrid bermudagrass cover 15 WAT, respectively; however, combining dazomet and glyphosate decreased cover to 6\%. Dazomet application $\left(583 \mathrm{~kg} \cdot \mathrm{ha}^{-1}\right)$ following fluazifop + glyphosate resulted in similar bermudagrass cover from 8 to 46 WAIT when incorporated with irrigation ( $0 \%$ to $2 \%$ ) or tilled $\mathrm{fb}$ rolled $\mathrm{fb}$ tarped ( $0 \%$ to $1 \%)$. Dazomet soil incorporation via irrigation is comparably a less 
Table 2. Pearson correlation coefficients for the relationship between bermudagrass cover determined by visual estimates and grid intersection counts at Raleigh, NC and College Station, TX.

\begin{tabular}{|c|c|c|c|c|}
\hline & \multicolumn{2}{|c|}{ North Carolina } & \multicolumn{2}{|c|}{ Texas } \\
\hline & 15 WAIT $^{z}$ & 46 WAIT & 16 WAIT & 42 WAIT \\
\hline & \multicolumn{4}{|c|}{ Intersect cover ${ }^{\mathrm{y}}$} \\
\hline Visual cover ${ }^{\mathrm{x}}$ & 0.97 & 0.92 & 0.91 & 0.99 \\
\hline$P$ & $<0.0001$ & $<0.0001$ & $<0.0001$ & $<0.0001$ \\
\hline
\end{tabular}

${ }^{2}$ Weeks after initial treatment; evaluation dates were North Carolina = 12 Sept. 2015 and 22 Apr. 2016, Texas = 20 Oct. 2015 and 7 Apr. 2016

${ }^{\mathrm{y}}$ Intersect cover $=[($ Binter $/$ Tinter $) \times 100]$, where Binter and Tinter equal the number of intersections with bermudagrass intersection counts and the total number of intersections, respectively.

${ }^{x}$ Visual cover estimated on $0 \%$ (no cover) to $100 \%$ (complete cover) scale.

Table 3. Common bermudagrass cover following applications of dazomet (DAZ), fluazifop (FLU), and glyphosate (GLY) in Raleigh, NC.

\begin{tabular}{|c|c|c|c|c|}
\hline \multirow[b]{3}{*}{ Herbicide $\left(\mathrm{kg} \cdot \mathrm{ha}^{-1}\right)^{\mathrm{z}}$} & \multirow[b]{3}{*}{ DAZ incorporation } & \multicolumn{3}{|c|}{ WAIT $^{\mathrm{y}}$} \\
\hline & & 8 & 15 & 46 \\
\hline & & \multicolumn{3}{|c|}{ Cover $(\%)^{x}$} \\
\hline DAZ (291) & Irrigate & 69 & 75 & 76 \\
\hline FLU + GLY fb DAZ (29l) & Irrigate & 1 & 4 & 6 \\
\hline DAZ (291) fb DAZ (291) & Irrigate & 45 & 70 & 78 \\
\hline FLU + GLY fb DAZ (291) fb DAZ (291) & Irrigate & 0 & 2 & 3 \\
\hline DAZ (468) & Till fb roll & 61 & 71 & 78 \\
\hline DAZ (583) & Irrigate & 83 & 85 & 85 \\
\hline DAZ (583) & Till fb roll & 63 & 75 & 83 \\
\hline FLU + GLY fb DAZ (583) & Irrigate & 0 & 2 & 1 \\
\hline FLU + GLY fb DAZ (583) & Till fb roll & 2 & 7 & 10 \\
\hline FLU + GLY fb DAZ (583) & Till $\mathrm{fb}$ roll $\mathrm{fb}$ tarp & 0 & 1 & 1 \\
\hline $\mathrm{FLU}+\mathrm{GLY}$ & - & 3 & 19 & 30 \\
\hline $\mathrm{FLU}+\mathrm{GLY}$ & Till & 14 & 45 & 55 \\
\hline $\mathrm{FLU}+\mathrm{GLY}$ fb FLU + GLY & - & 0 & 4 & 5 \\
\hline FLU + GLY fb FLU + GLY fb FLU + GLY & - & 0 & 1 & 1 \\
\hline Nontreated & Till & 18 & 45 & 68 \\
\hline Nontreated & - & 91 & 88 & 86 \\
\hline $\operatorname{LSD}_{0.05}{ }^{\mathrm{w}}$ & & 20 & 15 & 12 \\
\hline
\end{tabular}

$\mathrm{fb}=$ followed by; LSD = least significant difference.

${ }^{2}$ FLU applied at $0.4 \mathrm{~kg} \cdot \mathrm{ha}^{-1}$ and GLY applied at $2.8 \mathrm{~kg} \cdot \mathrm{ha} \mathrm{h}^{-1}$ acid equivalent; $1 \mathrm{~kg} \cdot \mathrm{ha}^{-1}=0.8922 \mathrm{lb} / \mathrm{acre}$.

yeeks after initial treatment; evaluation dates were 28 July 2015, 12 Sept. 2015, and 22 Apr. 2016.

${ }^{x}$ Visual cover estimated on $0 \%$ (no cover) to $100 \%$ (complete cover) scale.

wLSD $(P<0.05)$ for comparing common bermudagrass cover resulting from treatment regimens within a respective evaluation date.

costly, intensive practice to tillage and tarping.

All non-dazomet treatments (i.e., fluazifop + glyphosate-alone treatments and nontreated-tilled) in North Carolina resulted in comparable bermudagrass cover at 8 WAIT $(0 \%$ to $18 \%)$, whereas at least two fluazifop + glyphosate applications were required to maintain bermudagrass cover $\leq 5 \%$ cover at 15 and 46 WAIT (Table 3 ). This agrees with Johnson (1988), who reported three glyphosate applications $(2.2,3.4$, or $4.5 \mathrm{~kg} \cdot \mathrm{ha}^{-1}$ ) resulted in $\leq 1 \%$ hybrid bermudagrass cover in the spring following fall applications, whereas $\leq$ two applications resulted in $30 \%$ to $72 \%$ cover. The effect of fluazifop and for herbicide translocation to subsurface plant tissue before tillage commenced, which allowed for regrowth from unaffected rhizomes/roots.

Compared with North Carolina, all Texas treatments had a more pronounced effect on bermudagrass cover through 10 WAIT. Excluding irrigation-incorporated dazomet $\left(291 \mathrm{~kg} \cdot \mathrm{ha}^{-1}\right)$ and nontreated-tilled, all treatments resulted in $\leq 14 \%$ cover through 10 WAIT (Table 4). In addition, all treatments including fluazifop + glyphosate resulted in $\leq 2 \%$ cover. At 16 WAIT, dazomet application $\left(468\right.$ or $583 \mathrm{~kg} \cdot \mathrm{ha}^{-1}$ ) reduced bermudagrass cover $(20 \%$ and $2 \%$ cover, respectively) more than 291 $\mathrm{kg} \cdot \mathrm{ha}^{-1}(66 \%)$; however, adding fluazifop + glyphosate to the low-rate treatment decreased cover $20 \%$. Sequential application at $29 \mathrm{l} \mathrm{kg} \cdot \mathrm{ha}^{-1}$ (19\% cover) did not significantly improve efficacy compared with a single application at $583 \mathrm{~kg} \cdot \mathrm{ha}^{-1}(35 \%)$; however, increased efficacy may be biologically significant to warrant recommending sequential applications to practitioners. Tillage incorporation resulted in lower cover than irrigation incorporation following application at $583 \mathrm{~kg} \cdot \mathrm{ha}^{-1}$ (2\% and $35 \%$, respectively). Non-dazomet treatments resulting in $\leq 5 \%$ bermudagrass cover at 16 WAIT included fluazifop + glyphosate fb tillage, and both fluazifop + glyphosate sequential application treatments. A pronounced increase in bermudagrass cover was observed in many Texas plots from 16 to 42 WAIT. At 42 WAIT, all dazometalone treatments resulted in $\geq 65 \%$ cover. Fluazifop + glyphosate before dazomet application $\left(291 \mathrm{~kg} \cdot \mathrm{ha}^{-1}\right) \mathrm{re}$ duced bermudagrass cover by $54 \%$ and $44 \%$ in single and sequential treatments, respectively. In addition, single and sequential dazomet applications $\left(291 \mathrm{~kg} \cdot \mathrm{ha}^{-1}\right)$ resulted in comparable cover $(45 \%$ and $53 \%)$ following fluazifop + glyphosate application. Tillage incorporation improved efficacy following fluazifop + glyphosate fb dazomet $\left(583 \mathrm{~kg} \cdot \mathrm{ha}^{-1}\right) \mathrm{com}-$ pared with irrigation incorporation; however, plots that were tilled and tarped did not differ from tilled, nontarped plots. As in North Carolina, three fluazifop + glyphosate applications resulted in $\leq 5 \%$ cover at 42 WAIT.

Across both locations, fluazifop + glyphosate $\mathrm{fb}$ tillage-incorporated 
Table 4. Common bermudagrass cover following applications of dazomet (DAZ), fluazifop (FLU), and glyphosate (GLY) in College Station, TX.

\begin{tabular}{|c|c|c|c|c|c|}
\hline \multirow[b]{3}{*}{$\underline{\text { Herbicide }\left(\mathrm{kg} \cdot \mathrm{ha}^{-1}\right)^{\mathrm{z}}}$} & \multirow{3}{*}{$\begin{array}{c}\mathrm{DAZ} \\
\text { incorporation }\end{array}$} & \multicolumn{4}{|c|}{ WAIT $^{y}$} \\
\hline & & 5 & 10 & 16 & 42 \\
\hline & & \multicolumn{4}{|c|}{ Cover $(\%)^{\mathrm{x}}$} \\
\hline $\operatorname{DAZ}(291)$ & Irrigate & 13 & 36 & 66 & 99 \\
\hline FLU + GLY fb DAZ (291) & Irrigate & 0 & 2 & 20 & 45 \\
\hline $\operatorname{DAZ}(291)$ fb DAZ (291) & Irrigate & 0 & 14 & 19 & 97 \\
\hline FLU + GLY fb DAZ (29l) fb DAZ (29l) & Irrigate & 0 & 2 & 3 & 53 \\
\hline $\operatorname{DAZ}(468)$ & Till fb roll & 1 & 2 & 20 & 75 \\
\hline DAZ $(583)$ & Irrigate & 2 & 12 & 35 & 99 \\
\hline DAZ $(583)$ & Till fb roll & 0 & 1 & 2 & 65 \\
\hline FLU + GLY fb DAZ (583) & Irrigate & 0 & 2 & 13 & 58 \\
\hline FLU + GLY fb DAZ (583) & Till fb roll & 0 & 0 & 0 & 4 \\
\hline FLU + GLY fb DAZ (583) & Till $\mathrm{fb}$ roll $\mathrm{fb}$ tarp & 0 & 0 & 0 & 4 \\
\hline $\mathrm{FLU}+\mathrm{GLY}$ & - & 1 & 7 & 33 & 79 \\
\hline $\mathrm{FLU}+\mathrm{GLY}$ & Till & 0 & 2 & 1 & 49 \\
\hline $\mathrm{FLU}+\mathrm{GLY} \mathrm{fb} \mathrm{FLU} \mathrm{+} \mathrm{GLY}$ & - & 0 & 1 & 5 & 39 \\
\hline $\mathrm{FLU}+\mathrm{GLY}$ fb FLU + GLY fb FLU + GLY & - & 0 & 0 & 0 & 5 \\
\hline Nontreated & Till & 15 & 44 & 67 & 96 \\
\hline Nontreated & - & 100 & 100 & 100 & 100 \\
\hline $\operatorname{LSD}_{0.05}{ }^{\mathrm{w}}$ & & 9 & 20 & 35 & 38 \\
\hline
\end{tabular}

$\mathrm{fb}=$ followed by; LSD $=$ least significant difference

${ }^{2}$ FLU applied at $0.4 \mathrm{~kg} \cdot \mathrm{ha}^{-1}$ and GLY applied at $2.8 \mathrm{~kg} \cdot \mathrm{ha}^{-1}$ acid equivalent; $\mathrm{l} \mathrm{kg} \cdot \mathrm{ha}^{-1}=0.8922 \mathrm{lb} /$ acre

'Weeks after initial treatment; evaluation dates were 28 July 2015, 27 Aug. 2015, 11 Oct. 2015, and 7 Apr. 2016. ${ }^{x}$ Visual cover estimated on $0 \%$ (no cover) to $100 \%$ (complete cover) scale.

${ }^{w_{L S D}}(P<0.05)$ for comparing common bermudagrass cover resulting from treatment regimens within a respective evaluation date.

dazomet at $583 \mathrm{~kg} \cdot \mathrm{ha}^{-1}$, which is the maximum labeled rate for soil incorporation on golf course fairways, resulted in $\leq 10 \%$ bermudagrass cover at the final evaluation date. Tarping after tillage did not improve efficacy at the maximum labeled rate, and consequently is not recommended for common bermudagrass renovations to save management resources and reduce potential dazomet-worker exposure. Three fluazifop + glyphosate applications resulted in $\leq 5 \%$ cover at the final evaluation date, and should be considered for renovations where tillage is not feasible. However, this treatment may not be practical due to time constraints commonly encountered during turfgrass renovations. Comparing fluazifop + glyphosate $\mathrm{fb}$ dazomet and three fluazifop + glyphosate applications, dazomet reduces the treatment duration from 56 to 8 d. Even with recommended plant backdates ranging from 8 to $15 \mathrm{~d}$ (from 25 to $15{ }^{\circ} \mathrm{C}$ soil temperatures at 4 inches depth) after dazomet application, substantial time savings are possible. This is an important consideration for golf courses, as revenue losses during the renovation period may be reduced, because the establishment period for the newly planted turf can be substantially decreased.
Overall, treatments reduced common bermudagrass more in Texas at the earlier evaluation dates; however, many treatments resulted in higher cover than in North Carolina by the final evaluation. This may be due in part to more favorable growing conditions in North Carolina through the summer following dazomet treatment, and their effect on common bermudagrass growth. Excluding irrigation treatments per protocol description, plots were not irrigated to supplement rainfall following dazomet application. Precipitation from June to September in North Carolina (21 inches water) and Texas (7 inches water) totaled $118 \%$ and $53 \%$ of the 30 -year average, respectively (data not shown). This may have created comparably more favorable common bermudagrass growth conditions in North Carolina than Texas, which resulted in reduced efficacy in North Carolina. In addition, warmer climatic conditions in Texas may have created more favorable conditions for common bermudagrass recovery. Bermudagrass dormancy commences when soil temperatures at a 4 inches depth fall below $10{ }^{\circ} \mathrm{C}$ (Christians, 2004). Average North Carolina soil temperatures in January and February were 6 and $7{ }^{\circ} \mathrm{C}$, respectively, and bermudagrass dormancy was observed from December to February (personal observation). Average Texas soil temperatures in January and February were 11 and $13{ }^{\circ} \mathrm{C}$, respectively, and bermudagrass dormancy was not observed (personal observation). An extended growing period in Texas may have created more favorable conditions for common bermudagrass regrowth.

Research implications. The presented research builds upon previous efforts evaluating dazomet for established bermudagrass removal. More specifically, this research provides information on recently modified dazomet application methods and rates per registered labeling. Results agree with preceding efforts, which found that additional herbicide inputs are often required before dazomet application for acceptable bermudagrass control. Building on this, future research should determine if fluazifop aids glyphosate efficacy, which may provide cost savings for turfgrass managers. In addition, reduced glyphosate application rates should be evaluated. Dazomet soilincorporation practices variably affected common bermudagrass across locations, with irrigation incorporation only providing acceptable results for practitioners in North Carolina. Tillage incorporation resulted in $\leq 10 \%$ common bermudagrass cover at the maximum labeled application rate on golf course fairways (583 $\mathrm{kg} \cdot \mathrm{ha}^{-1}$ ) through the final evaluation dates at both locations, and should be employed where feasible. Tarping areas after tillage did not improve efficacy, and can be avoided. Overall, using dazomet for bermudagrass removal can substantially reduce renovation periods compared with programs relying solely on herbicides. By doing so, golf course revenue losses associated with regrassing areas may be reduced.

It should be noted that the presented research does not align with in situ management approaches, as plots were not reestablished with a new turfgrass in the time frame that a renovation project would typically be conducted. This could have created more favorable conditions for common bermudagrass regrowth by excluding plant competition from the subsequent turfgrass stand, and ultimately reduced long-term dazomet 
efficacy. Future research should evaluate regrassing timings across pertinent species, as well as treatments including glyphosate + fluazifop and dazomet application rates, incorporation methods, and timings across additional climates and edaphic conditions.

\section{Literature cited}

Amvac Chemical Corp. 2014. Basamid ${ }^{\circledR}$ fumigant label. Amvac label no. 138962012201417. Amvac Chemical Corp., Los Angeles, CA.

Branham, B.E., G.A. Hardebeck, J.W. Meyer, and Z.J. Reicher. 2004. Turfgrass renovation using dazomet to control Poa annua L. soil seed bank. HortScience 39:1763-1767.

Brosnan, J.T. and G.K. Breeden. 2009. Surface applications of dazomet provide nonselective control of seashore paspalum (Paspalum vaginatum) turf. Weed Technol. 23:270-273.

Carmer, S.G., W.E. Nyquist, and W.M. Walker. 1989. Least significant differences for combined analyses of experiments with two- or three-factor treatment designs. Agron. J. 81:665-672.

Christians, N.E. 2004. Fundamentals of turfgrass management. 2nd ed. Wiley, Hoboken, NJ.
Doroh, M.C., J.S. McElroy, E. van Santen, and R.H. Walker. 2011. Conversion of 'Tifway' bermudagrass stands to 'Zorro' zoysiagrass turf using combinations of dazomet and EPTC. Weed Technol. 25:631-636.

Ferrell, J.A., T.R. Murphy, and D.C. Bridges. 2005. Postemergence control of hybrid bermudagrass (Cynodon dactylon transvaalensis Burtt-Davy $\times$ Cynodon dactylon). Weed Technol. 19:636-639.

Fritsch, H.J. and R. Huber. 1995. Basamid granular: A halogen-free soil disinfestant. Acta Hort. 382:76-85.

Hoyle, J.A., F.H. Yelverton, and T.W. Gannon. 2013. Evaluating multiple rating methods utilized in turfgrass weed science. Weed Technol. 27:362-368.

International Sports Turf Research Center. 2016. Aerification displacement chart. 14 Sept. 2016. <http://www.istrc.com/ documents/ISTRCDisplacementChart. $\mathrm{pdf}>$.

Johnson, B.J. 1988. Glyphosate and SC0224 for bermudagrass (Cynodon spp.) cultivar control. Weed Technol. 2:20-23.

Lyman, G.T., C.S. Throssell, M.E. Johnson, G.A. Stacey, and C.D. Brown. 2007. Golf course profile describes turfgrass landscape and environmental stewardship features. Appl. Turfgrass Sci. doi: 10.1094/ATS-2007-1107-01-RS.
Park, B.S. and P.J. Landschoot. 2003. Effect of dazomet on annual bluegrass emergence and creeping bentgrass establishment in turf maintained as a golf course fairway. Crop Sci. 43:1387-1394.

Steel, R.D., J.H. Torrie, and D.A. Dickey. 1997. Principles and procedures of statistics: A biometrical approach. 3rd ed. McGraw Hill, New York, NY.

Turgeon, A.J. 2008. Turfgrass management. 8th ed. Pearson, Upper Saddle River, NJ.

United Nations Environment Program. 2009. Handbook for the Montreal Protocol on substances that deplete the ozone layer. 14 Sept. 2016. <http:// www.ozone.unep.org/Publications/ MP_Handbook/MP-Handbook-2009. pdf>.

Unruh, J.B., B.J. Brecke, J.A. Dusky, and J.S. Godbehere. 2002. Fumigant alternatives for methyl bromide prior to turfgrass establishment. Weed Technol. 16:379387.

U.S. Environmental Protection Agency. 2016. Methyl bromide. 14 Sept. 2016. <https://www.epa.gov/ods-phaseout/ methyl-bromide $>$.

Webster, T.M., C.W. Bednarz, and W.H. Hanna. 2003. Sensitivity of triploid hybrid bermudagrass cultivars and common bermudagrass to postemergence herbicides. Weed Technol. 17:509-515. 